\title{
Defending Informal Workers' Welfare Rights: Trade Union Struggles in Tamil Nadu
}

\author{
K. Kalpana, Indian Institute of Technology Madras, India
}

\begin{abstract}
The South Indian state of Tamil Nadu has had a rich history of informal workers' movements and struggles that have pressured the state government to enact statutory schemes and set up worker welfare boards to extend social protection to informal workers. This article discusses the efforts of two prominent trade unions in the state to secure welfare benefits for informal workers, and explores the primary challenges, conflicts and dilemmas they have faced. It explores the troubled interfaces between trade unions and the worker welfare boards that the unions regard as the fruit of workers' struggles and collective organising of the past. The unions have used the welfare boards to mobilise new occupational categories of workers as well as women workers in the lower rungs of the informal sector. At the same time, the welfare boards are a double-edged sword that the unions must carefully manage given the frustration and disappointments that ensue when the promise of social protection remains elusive to workers. Placing this case study in the larger context of labour movements across the world that have won contingent victories in protecting workers' interests and well-being, the article raises troubling questions regarding the implications of these victories in neo-liberal state regimes.
\end{abstract}

\section{KEY WORDS}

informal workers; trade unions; welfare rights; labour organising; Tamil Nadu

\section{Introduction}

There has been a growing informalisation of the workforce as a consequence of neo-liberal policies of economic restructuring adopted in India since the 1990s and in many other parts of the world a decade earlier. Policies of economic deregulation and financial liberalisation have facilitated capital's pursuit of flexible, casual, irregular or contract labour subject to market logics of hire and fire rather than statutory regulations (Standing, 1999; Breman, 2001; Ghosh, 2002; Srivastava, 2012). And yet, despite macro policies that privilege capital over the rights and interests of labour, workers' movements and trade unions in diverse regional contexts have wrested concessions from liberalising governments, pressuring them to pass legislation and initiate or strengthen protective policies favouring workers' rights and well-being (Cook, 2007; Baltar et al, 2010; Agarwala, 2013). This article briefly reviews the literature discussing the political-economic compulsions that have motivated national governments implementing neo-liberal economic policies to advance workers' rights or stall adversarial policies hurting workers' interests. The article subsequently focuses on the specific case of informal workers winning welfare and social protection rights in a South Indian state and raises the question of what happens once these rights are conceded by the state. Are trade unions able to defend newly won rights by holding governments to the promises embodied in 
progressive legislation and policy initiatives? Have unions demonstrated the capacity to build on the gains by winning the confidence of informal workers, thereby extending union presence and strength among hitherto unorganised sections of workers? In order to explore these issues, the article discusses in detail the primary challenges, conflicts and dilemmas that emerge when trade unions engage government-sponsored social protection initiatives in order to claim welfare benefits for informal workers (especially women workers) in the South Indian state of Tamil Nadu. The article also places the particular case study in the larger context of labour movements that have won contingent victories in contemporary times, and raises troubling questions regarding the implications of some of these victories in liberalising state regimes.

Scholars remind us that even when macroeconomic policies have been explicitly neo-liberal in their orientation and have favoured labour flexibility in principle, labour reform in actuality may not necessarily reflect this preoccupation. For instance, in Argentina and Brazil, a political context of transition to democracy from authoritarian rule (in the 1980s) expanded protection and rights for labour, that were not rolled back in the neo-liberal era of the 1990s, even if governments sought to weaken them. Besides the presence of strong unions, pre-existing national labour laws in the two countries bestowed organisational resources and collective rights upon labour unions that served them well during difficult times (Cook, 2007). In Argentina, Uruguay and Brazil, leftist governments that came to power in the 2000s pursued policies that strengthened trade unions' capacities to engage in effective collective bargaining, included unions in policy-making and social dialogue and enhanced the collective rights of workers, even while the new governments continued to pursue the market-oriented policies of their predecessor regimes (Cook and Bazler, 2013). The need of President Lula's government in Brazil to respond to social demands for income and employment generation and the role of public institutions in monitoring compliance with labour legislation created an environment in which the trade union movement was able to go beyond merely defending jobs to winning back lost rights and broadening its demands (Baltar et al., 2010).

In South Africa, the Congress of South African Trade Unions (COSATU), an important player in the anti-apartheid struggle, and subsequently the configuration that came to power postapartheid, managed to put in place legislation that protected the associational rights of workers, regulated working conditions and extended benefits at work to formal-sector workers. The new laws were amended in 2002 with a view to benefiting and including informal workers by, for instance, allowing the Ministry of Labour to designate any group of workers (including subcontracted and home-based workers) as employees covered by labour laws. These legislative changes have taken place even as South Africa has embarked on a neo-liberal growth strategy that has produced tensions within the ruling alliance for the representatives of labour (Bennett, 2003; Torres, 2005). In China, the introduction of protective labour legislation in the 1990s and the 2000s was part of a revised social contract wherein the Chinese party-state sought to ensure worker quiescence in return for legal protection of workers' rights, a more effective trade union presence in private enterprises at the grass roots and the provision of social welfare. The growing concern of China's political leadership at increasing worker unrest in the 1980s, partly in response to a growing commodification and casualisation of labour and the smashing of the Chinese "iron rice bowl", was seen to have provoked these initiatives (Howell, 2015). As the literature suggests, varied factors such as a "political legacy" of labour laws, institutions and alliances (Cook, 2007), pressure from labour organising to protect its interests and/or the compulsions of national governments implementing neo-liberal economic reforms that created disaffection among the working poor have provided openings and opportunities for protection and advance of (some) interests and rights of different sections of workers.

India's experience with neo-liberal reforms launched in the early 1990s has likewise been 
tempered and shaped by the "path dependencies" of a strong state tradition, constitutional design, vigorous social movements that foregrounded social and economic rights, and popular democracy (Harriss, 2011). Chatterjee (2008) underscores the political/electoral unfeasibility of abandoning the country's dispossessed poor in a representative democracy to the ongoing processes of primitive accumulation unleashed by the ascendance of corporate capital since the 1990s. The continuance of government provisioning of welfare-oriented and anti-poverty relief has therefore sought to reverse the effects of primitive accumulation (Chatterjee, 2008). It is in such a nationalpolitical context that we may situate the Indian state's favourable response to the bottom-up pressures from informal workers who have organised themselves in different parts of India. As Agarwala (2013) describes, informal workers' movements and unions in India, rather than making demands of private capital, invoke citizenship claims vis-à-vis the state for guaranteeing the welfare rights of workers such as health care, education, pensions, housing and other social security benefits. A citizenship-centred rights rhetoric was particularly useful to articulate the aspirations of informal workers (many of them home-based and sub-contracted workers) who laboured within production structures that confounded traditional trade union strategies of battling employers in designated workplaces. The welfare entitlements of informal workers are usually delivered through industry-specific, tripartite welfare boards set up for this purpose by a number of state governments in India (Agarwala, 2013).

The following section provides a brief outline of the emergence of informal workers' movements in Tamil Nadu and the response of the state government via legislation and the creation of welfare boards. The subsequent section introduces the two trade unions whose experiences of claiming informal workers' welfare benefits through the welfare boards form the subject of this article.

\section{Informal Workers' Movements and the State in Tamil Nadu}

Tamil Nadu's competitive, populist political parties, the Dravida Munnetra Kazhagam (DMK) and the All India Anna Dravida Munnetra Kazhagam (AIADMK) have provided informal workers the opportunity to mobilise and demand social rights and civic amenities from state governments in power. The high levels of mobilisation in the public sphere which enabled the rise of Dravidian parties in Tamil Nadu and the "assertive populism" they fostered, encouraged excluded social groups (such as intermediate castes who were small property holders) to assert themselves against the social discrimination they faced and to proactively secure entitlements to employment, education, loans and so on. Subramanian (1999) argues that this "assertive populism" fuelled by competition between the two principal Dravidian parties accounts for the sustained success of populism in Tamil Nadu. Agarwala's (2013) comparative study of the interaction between regional governments and informal workers' movements in three states in India (Maharashtra, West Bengal and Tamil Nadu) found that the government of Tamil Nadu had extended more welfare benefits to informal workers than any other state. The relative attainment of social rights by Tamil Nadu's workers is attributed to political parties' interest in canvassing votes and the corresponding success of informal workers' organisations in mobilising their members as vote banks for the state's politicians.

Tamil Nadu has been home to vibrant movements of informal workers, especially construction workers, widely regarded as an inspiration for informal workers' movements in the country at large. In the late 1970s and early 1980s, a newly formed Tamil Nadu Construction Workers Union spearheaded mass campaigns and agitation-centred public action demanding minimum wages, 
social security and the formation of tripartite labour boards to protect the interests of construction workers. Several waves of public demonstrations in the state capital and the districts led to the passing of the Tamil Nadu Manual Workers (Regulation of Employment and Conditions of Work) Act in 1982. Through this Act, Tamil Nadu was the first Indian state to recognise that all manual labourers must be protected by state legislation irrespective of an existing employer-employee relationship. The Act provided for the formulation of social security and welfare schemes for construction as well as other manual workers in the informal sector and the establishment of welfare boards to implement these schemes (Geetha, 1996; PRS, n.d).

While it was construction workers who had agitated for state protection, the inclusion of other manual workers in the 1982 Act underscored the intention of the (then) Chief Minister M.G. Ramachandran (of the AIADMK) to appeal to a broader group of informal workers during an election year (Agarwala, 2013: 1999). Another wave of protest action by construction workers in the early 1990s led to the setting up of a Construction Workers Welfare Board in November 1994 when J. Jayalalitha (AIADMK) was Chief Minister. As R. Geetha, leading organiser of independent informal workers' movements in Tamil Nadu said to this researcher, the creation of the board paved the way for vociferous demands and organised action from other informal workers asking why only construction workers merited a welfare board. Subsequently, in March 1999, the DMKled state government headed by M. Karunanidhi set up a Manual Workers Social Security and Welfare Board in order to extend welfare benefits to workers in diverse categories of employment such as loading and unloading work, employment in the timber industry, automobile workshops, bullock cart driving, collecting forest produce and so on (GOTN, n.d).

Tamil Nadu currently has a total of thirty-four industry-specific welfare boards for informal workers, seventeen of which function under the administrative control of the Department for Labour and Employment ${ }^{1}$ and seventeen under other departments of the state government. The welfare boards for informal workers implement the state government's schemes for workers of both sexes such as monetary assistance in case of natural death, accident-induced death or disability, as well as funerals of workers, monthly disability pension, old age pension, marriage assistance, education stipends for the children of workers, and maternity benefits, assistance for miscarriage and medical termination of pregnancy for women workers. By the end of March 2018, the seventeen welfare boards controlled by the Department for Labour and Employment had a total of 7.1 million workers registered as members, of whom 4.3 million had received welfare benefits amounting to a total of Indian Rupees (INR) 12.35 billion (GOTN, 2018: 32-40).

\section{Organisations Interviewed and Study Methods}

The two trade unions whose experiences with the welfare boards form the basis of this article include the Tamil Nadu Kattida Thozhilalar Panchayat Sangam (KTPS, the Tamil Nadu Construction Workers Panchayat Union), a non-party-affiliated trade union, and the Centre for Indian Trade Unions (CITU) affiliated to the Communist Party of India (Marxist), the CPI(M). Both organisations were selected for this study as they had played an important role in leading workers' movements in Tamil Nadu with a perspective that extended well beyond service delivery to encompass worker education, political conscientisation and linking the livelihood rights of

\footnotetext{
1 Apart from the construction workers' and manual workers' boards, the other boards in the Labour Department cater to specific categories of workers including domestic workers, unorganised drivers, hairdressers, tailors, handicraft, handloom and silk weaving workers, footwear, leather goods and tannery workers, and so on (GOTN, 2018: 32-40).
} 
workers to broader struggles for progressive social change and economic justice. ${ }^{2}$ The KTPS emerged from several waves of organising and struggles of construction workers in the state that began in the late 1970s. It has been an integral part of state-level and national campaigns that have pushed the state and central governments to enact legislation recognising the rights and entitlements of construction workers. In Tamil Nadu, the union is currently active in twenty districts and has a membership of approximately 27000 workers, 30 per cent of whom are women (R. Geetha, interview, 25 January 2018). ${ }^{3}$ The CITU is a nationally prominent trade union which built its base in Tamil Nadu by organising industrial workers in factories and workshops. It has vigorously organised informal workers across the state since the mid-to-late 1990s. Of a total membership of about 520000 workers in Tamil Nadu, 60 per cent are drawn from workers in the informal sector, and about 20 per cent of all union members (formal and informal workers) are women workers (Malathi Chittibabu, interview, 1 August 2018). ${ }^{4}$ Both CITU and KTPS have engaged extensively with the worker welfare boards seeking to realise the promise of social protection for informal workers that these boards embody.

This article draws on in-depth and semi-structured interviews and open-ended discussions conducted between August 2017 and August 2018 with leading organisers of the KTPS and the CITU at the state level and at the district level in two districts - Madurai (KTPS) and Chennai (CITU). In Madurai district, the KTPS has a membership of about 1000 construction workers, with 70 per cent of them being women workers. The district leadership in Madurai has consciously prioritised organising women workers. The CITU's Informal Sector Workers Union in Chennai district was set up in 2008 and has about 5000 workers in this region. While the union is open to men and women, its members are predominantly women petty commodity or service producers who sell flowers, fruits, vegetables and home-cooked meals and snacks, or carry out retail trade such as saree sales.

The following section discusses the emergence of synergistic relationships between the welfare boards and the trade unions of this study in Tamil Nadu. While the formation of the welfare boards enabled the unions to expand their base among informal workers, the unions, in turn, pressured successive state governments to strengthen the welfare boards and extend their social protection cover.

\section{Welfare Boards and Workers' Unions: Synergistic Relationships}

In the early 1990s, India's central government adopted liberalisation policies consisting of the standard policy prescriptions of the International Monetary Fund (IMF) and the World Bank short-term stabilisation and medium- and long-term structural adjustment measures. The growth of informal employment in the economy at large and even within the formal sector where workers began to feel the adverse effects of the economic liberalisation policy made it impossible for the established national trade union federations in the country to ignore the informal workforce (Bhowmik, 2009). In Tamil Nadu, the CITU, goaded by its central leadership, felt an acute need to increase its organisational strength among informal workers. The opportunity to mobilise informal workers in Tamil Nadu emerged in the mid to late 1990s after the creation of the Construction

\footnotetext{
2 The study was conducted as part of a research project on Feminist Analysis of Social and Solidarity Economy Practices, funded by the French Institute of Pondicherry and the Swiss Network of International Studies (SNIS).

${ }^{3} \mathrm{R}$. Geetha is the founder of the KTPS in Tamil Nadu.

${ }^{4}$ Malathi Chittibabu is the State Treasurer of the CITU.
} 
Workers and Manual Workers Welfare Boards. While the CITU had mobilised some sections of informal workers (such as fish workers and auto drivers) well before the boards came into being, the establishment of the boards enabled the union to reach out to new categories of workers as well as to extend the influence of existing unions. R. Singaravelu, the State Vice-President of the CITU, put it thus:

After LPG (liberalisation, privatisation, globalisation) policies, informal sector workers grew in number. Whether you like it or not, you have to unionise the unorganised if you want to strengthen your union.... We have a CITU union for construction workers in Coimbatore [district] for forty years now. But we could pick up momentum to expand this union and organise construction workers in other districts only after the [construction] board was formed. Also, we were able to form unions among power-loom workers, road transport workers, private lorry and school van drivers, tailors, hairdressers and potters after the welfare boards were created (R. Singaravelu, interview, 6 July 2018).

When the welfare boards began to offer maternity benefits and other social security schemes from the late 1990s, the CITU realised that there was great need to make women workers, who were mostly employed in the lowest rungs of the informal sector as construction or domestic workers, aware of the existence of the boards. Malathi Chittibabu, State Treasurer of the CITU, described how the welfare boards became "a tool to organise women workers" when union organisers described each social security scheme in meetings held in working-class neighbourhoods and urged women workers to simultaneously join the union and the welfare boards so that they could claim the financial resources and the social recognition (as workers) that the boards offered. Drawing on the experiences of organising garment workers in the informal economy in South Africa, Tilly et al. (2013) point out that the question of what membership in a union can do to improve informal workers' material situation is a legitimate concern that organisers cannot evade. Finding that the recruitment of informal workers to a union was far more time- and effort-intensive than was the case with formal workers, the South African unions recognised that they had to offer a range of non-traditional services to attract and retain garment workers from the informal economy. In our case, the unions found the social security schemes of the welfare boards a useful entry point to address and win the confidence of new constituencies of informal workers through the promise of concrete material benefits.

Since the formation of the boards, the KTPS and CITU have persistently demanded that they expand their scale of operation and the quantum of financial assistance delivered through their schemes. When the Construction Workers Welfare Board was set up in 1994, it offered just one scheme (INR 50000 for accident-induced death of a worker at a worksite) and its sphere of operation was limited to three major cities in the state. The board currently offers eight schemes and covers the entire state. R. Singaravelu (CITU) served as one of the representatives of manual workers' unions on the Construction Workers Welfare Board from 1995 to 2011. In the early years, when he suggested that the board introduce an old age pension for workers along the lines of the welfare board of the neighbouring state of Kerala, government officials reportedly responded saying, "A pension for manual workers? Why? Are they government employees?" Under sustained pressure from union representatives on the board and organisers outside from the KTPS and CITU, a monthly old age pension for all informal workers registered with the welfare boards was introduced in 2005, and the amount increased in stages from an initial INR 200 to INR 1000 in December 2011. The quantum of financial support for the natural death of workers and maternity assistance also rose over time "from a pittance", as R. Geetha (KTPS) put it, after unions fought for the increase. The trade unions have been vigilant in monitoring the functioning of the boards 
and intervening through all routes available to them - direct talks with government or street protests - to force a course correction, when they felt the circumstances warranted it. In 2002, the KTPS held a state-wide march starting on International Women's Day and culminating in a big rally in the state capital on May Day in order to counter a perceived indifference on the part of the (then) AIADMK-led state government to the welfare boards. The KTPS state leadership has also played an important role in helping build the struggles of groups of informal workers besides construction workers outside the ambit of left party-led trade unionism and assisting them to articulate their distinct demands vis-à-vis the welfare boards. This led to the formation of a broad platform - the Unorganised Workers Federation, comprising independent trade unions in 2006 with R. Geetha (KTPS) as founder and state coordinator.

The following section discusses the endeavours of both of the unions to make the welfare boards work for informal workers, women and men.

\section{Battling the Welfare Boards}

\section{Securing and retaining membership}

Workers aged between 18 and 60 years could register themselves with one of the worker welfare boards (depending on their occupation) and subsequently apply for welfare benefits. In order to register with a board, the worker required a certificate of employment from her employer or a registered trade union of the employment concerned. Since the end of 2008, a designated labour officer in each district was made responsible for administering the schemes of the seventeen welfare boards controlled by the Department of Labour and Employment. The labour officer is responsible for overseeing workers' registration with the boards, membership renewal and disbursal of benefits to workers in the district (TNMWWB, n.d: 44-48). All union organisers affirmed that a key procedural change instituted at the end of 2008 has had significant adverse repercussions for workers. The labour officers were allowed to register workers only after verification - that they are actually manual workers as stated - by the respective Village Administrative Officers (VAOs) in the districts or the Revenue Inspector (RI) in Chennai (TNMWWB, n.d.). The government ostensibly introduced this procedure to check some trade unions that encouraged workers to register with more than one welfare board or encouraged nonworkers to register with the boards. The trade unions interviewed for this study strongly felt that the government should have taken action against the unions that did so rather than vest VAOs and RIs with the power to authorise worker status. This has placed workers interacting with the welfare boards at the mercy of the Revenue Department's officialdom at the lower levels, leading to multiple allegations of harassment, delay and extortion.

Sasikala (KTPS Madurai district) reported that some VAOs challenged women construction workers saying, "You don't go for construction work every day, do you? I see you working elsewhere". Women construction workers did not always find work in construction and often worked seasonally or for short periods in farms and fields, doing domestic work in others' homes or selling wood that their husbands had cut. In such cases, the VAO or RI refused to issue the certificate if they were applicants seeking registration or removed their names from the rolls of the Construction Workers Welfare Board if they were already registered. Whenever this occurred, the union had to directly approach the officials and convince them that that the woman in question was primarily a construction worker. In one case, a construction worker in Madurai had worked two years in a small tailoring company, when she could not find employment in construction work. 
During this period, her employer deducted part of her salary as payment towards the Provident Fund and Employees State Insurance schemes. When she came back to construction work and sought access to a welfare scheme from the board, the deduction in her bank passbook was held as proof that she worked elsewhere. As a result, her membership in the Construction Workers Board was cancelled. The KTPS organisers directly sought out the owner of the tailoring unit, made him state in writing the two-year period she had worked in his unit and declare that she was no longer a worker in the company. After a period of three months and the union's many efforts, she was taken back as a member by the board.

These struggles to gain and retain membership in the welfare boards reveal the contradictions between the classification of workers demanded by the worker welfare boards (and those who have the power to interpret and apply its rules) on the one hand, and the shifting livelihoods and lifecircumstances of women workers in the informal sector on the other. They also indicate the magnitude of the intermediary work the unions had to perform in order to ensure workers' access to the boards. Union organisers of the KTPS estimated that they spent half their time getting construction workers registered and pursuing welfare schemes from the boards, even as they continued to take up issues such as part-payment of wages, accident compensation and other workplace benefits.

\section{Anti-worker procedure, rent-seeking and inadequate funds}

Formerly, trade unions could represent workers at the welfare boards and submit workers' identity documents on their behalf. As part of the changes introduced to check the registration of nonworkers, the system of union representation of workers at the boards was jettisoned. All workers have since been required to directly present themselves before the labour officer at the district headquarters for registration as well as each time they apply for a welfare scheme. The daily wages that workers lose and the travel expenses they bear can be considerable and make little sense when workers paid INR 600 or so seek a financial claim of INR 1000. A worker is required to produce her bank passbook, Voter Identity Card, ration card (that enables low-income households to access the public distribution system) and Aadhar card ${ }^{5}$ to register with a welfare board and whenever she applies for a welfare benefit. The union organisers confirmed that even if a word or letter in a document did not match the others, the board would reject the worker's application. For instance, all four personal identity documents have to show the same age for a worker even though it is wellknown that anomalies such as each document showing a different age are common among the poor, many of whom do not have birth certificates. In such cases, workers were turned away and asked to meet the district medical officer to obtain proof of age and set right discrepancies in identity documents. Union organisers reported that women workers sometimes flatly refused to become members of the welfare boards when they realised how harrowing and unsuited to their (paid and unpaid) work responsibilities the bureaucratic processes of the boards were.

Initiatives that were seemingly pro-worker did not always have the expected outcomes either. Workers' renewal of membership in the welfare boards, which used to be once in two years, was extended to five years in 2014. However, workers often forgot to renew membership and could not keep track of the renewal schedules when the period was extended. If a worker died without renewing membership, the welfare board rejected her family's claim for monetary assistance in case

\footnotetext{
${ }^{5}$ The Aadhaar card shows a twelve-digit Unique Identification Number issued by the Indian government that every Indian resident is expected to possess. Critics argue that the compulsory linkage of Aadhaar to welfare programmes across the country excludes the poor from benefits essential to their well-being (Khera, 2017).
} 
of death, funeral assistance and family pension. The trade union had to plead the worker's case with the welfare boards, requesting that money be released "as a one-time exemption given the condition of the worker's family". The CITU sent a notice to the Labour Commission asking that it send three reminders to workers to renew membership towards the end of the five-year period. The government's expectation, however, was that unions must undertake this responsibility. As union leaders pointed out, this called for data maintenance, software design and computers in all district offices, along with the required personnel to maintain the data. Besides the resources this would consume, the question was also one of whether trade unions that sought to prioritise consciousness-raising of their workers and intensify political education work at the grass roots could afford to function like a bureaucracy and incur costs in managing office infrastructure.

Another source of concern to unions was that the labour offices in the districts created since 2009 had imbibed and emulated the institutional culture of the "taluk offices" or block-level offices of the revenue administration that were notorious for rent-seeking and "where everyone has a rate", as R. Singaravelu (CITU) put it. The paucity of regular staff in the labour offices has also increased the work pressure on existing staff, leading to their indifferent handling and ad hoc rejection of workers' petitions for welfare claims. Vasanthi, organiser of the CITU Informal Sector Workers Union (Chennai district) said,

If we send a form asking for financial help for school education of a worker's child in June, it is rejected after six months. The reason they give is that the worker's name was not clearly visible or the form was folded where it should not have been (Vasanthi, interview, 19 March 2018).

Union organisers feared that the state government was trying to close the welfare boards by driving workers away since the boards, in any case, did not have adequate budgetary resources to finance the welfare benefit claims of informal workers. Generally, welfare boards were funded through worker contributions, government budgetary allocation and a welfare cess ${ }^{6}$ paid by employers. In Tamil Nadu, the welfare schemes of most of the boards were financed only through allocation of government grants. Of the welfare boards, only those for construction workers and unorganised drivers received a cess from construction employers and commercial motor transport employers respectively. In 2006, the (then) DMK state government had done away with workers' payment of registration and renewal fees to the boards although, as CITU organisers pointed out, the waiver of membership fees had not been raised as a demand by any trade union.

\section{Networks of influence}

It appeared that not all unions suffered equally at the hands of the welfare boards, the labour offices in the districts and the Revenue Department's bureaucracy. The Revenue Department's role in controlling registration with the welfare boards paved the way for networks of influence that favoured some unions and disadvantaged others. The KTPS organiser (Madurai district) reported that political-party-affiliated trade unions got financial benefits for workers more easily than independent unions like hers. The CITU organisers spoke of the local influence commanded by the principal political parties of Tamil Nadu, the DMK and the AIADMK. Local organisers of the parties used their political leverage to register manual workers residing in a locality with the board as a way of gaining influence in a local area. The unions strongly believed that the antipathy of the government to specific unions that were vigorous opponents of state economic policies, which

\footnotetext{
${ }^{6} \mathrm{~A}$ cess denotes a tax that is earmarked for a particular purpose and can be levied on a product, income or activity.
} 
they denounced as anti-poor or anti-worker, also played a part in rationing out the applications of their workers.

While the trade unions of the DMK and the AIADMK did not interact much with the welfare boards, non-governmental organisations (NGOs) that linked informal workers to the welfare boards had proliferated in each district after the advent of the boards and the labour offices. It was reported that about $400 \mathrm{NGOs}$ had mushroomed in each district of the state in order to link workers to the welfare boards and to secure welfare benefits for workers. As noted earlier, workers required an employment certificate from a trade union in order to register themselves with the welfare boards. Vasanthi (CITU Chennai district) reported that a few NGOs stationed themselves outside the welfare board offices with the official seal of their organisation and a letter pad. They were known in local parlance as the "letter pad union", indicating that the organisation's sole activity and purpose of existence was to register workers with the boards. For a fee, the NGO staff filled out workers' application forms for board membership and welfare schemes, affixed the seal and quickly processed the applications through their close links to welfare board and labour office employees. The flow of money (by transferring a portion of the fee extracted from workers) and "treats" such as coffee, tea and snack food from the NGOs to welfare board employees ensured quick processing of the applications they forwarded. Vasanthi said with regret, "Who will workers go to when they can pay something and get their work done? To us or the letter pad unions? We also call the workers for meetings and so on. This is a very big challenge!"

\section{Fragmenting Collectives, Fracturing Trust}

A combination of factors that include the Revenue Department's dominant role in the activities of the welfare boards, the denial of permission to unions to represent workers at the boards, harassment of workers via paperwork requirements, the insensitivity of the bureaucracy to the shifting livelihoods of informal workers (especially women workers), the arbitrary rejection of benefit claims on trivial grounds and unjustifiably long delays in processing applications have left unions and workers disillusioned and frustrated. It is important to note that while collective bargaining for workplace rights such as higher wages and better working conditions are likely to improve conditions for all workers, processing welfare claims has often led to mixed results and partial successes. A union branch of ten to twenty informal workers could dissolve due to the tensions generated if only five workers had their welfare benefit claims approved by the board when ten or more workers sought benefits. When grassroots organisers (also informal workers) who had worked very hard to create a local branch of the union did not get their own claims approved, all workers in the branch felt demoralised.

The literature on the labour transformation induced by neo-liberal globalisation notes that schisms among workers have increased in tandem with informalisation and a movement towards peripheral labour markets (Noiseux, 2016). A proliferation of multiple employment statuses has been associated with increased competition among workers, the breakdown of group solidarity and the heterogenising of the working class. Noiseux's study of contract workers in Mumbai's shipbreaking dockyards shows how workplace hierarchies, modes of labour recruitment and differences of caste and region of origin compound the effect of the multiplication of worker statuses. He notes that the ensuing conflicts both among informal workers and within the trade union emerge as key challenges, and that union organisers must find the tools and means to effectively address these issues (Noiseux, 2016). In our case, the modes of activism engendered by the welfare boards and the individual-oriented nature of welfare benefits are seen to undermine 
emergent solidarities among workers (as discussed above) and within the trade union as well. The latter was manifest in cases wherein second-rung union leaders or grassroots organisers, who had learned the ropes of handling the welfare boards, split away from the parent union. Not infrequently, these local leaders, who commanded the allegiance and loyalty of workers in their area of influence, started their own organisations, exploring opportunities to strike out on their own through welfare-board-oriented union activism. As Sasikala (KTPS Madurai district) explained, such tendencies towards fragmentation of the union had increased over the last decade, whittled down the union's strength and reflected the breakaway organisers' desire to "make money through union work".

Besides ties of solidarity among workers and within the trade union, relations of trust between workers and the unions also suffered when the promised welfare benefits did not materialise. All union organisers noted that a rejection of workers' welfare claims by the boards was widely interpreted as union failure. Some workers who paid their unions' annual membership fee were furious when they failed to obtain financial benefits from the welfare boards. Vasanthi (CITU Chennai district) recalled a woman worker accosting her on a public road saying, "You are eating all my money. A curse upon your family!" The unresponsiveness of the welfare boards had reportedly demotivated many self-employed women workers and reduced the union's active membership in Chennai district.

\section{Welfare Board Disappointments and Trade Union Responses}

This study found that the welfare boards and the vision of social security they represent have shaped workers' expectations of their unions and, at least partially, the relationships between workers and their unions. Workers expected that unions would successfully mediate their troubled relationship with state bureaucracy and guarantee access to the promised financial benefits. If the unions could not do so, despite the efforts they made, they ran the risk of being seen as failed intermediaries who had let down the workers. This was the case especially when unionists centrestaged the welfare boards and their benefits when recruiting informal workers. The unions had to convince workers not to give up on the boards and remind them repeatedly that the boards were the institutional embodiment of long-fought and hard-won workers' struggles in the past. At the same time, the unions of this study (KTPS and CITU) were painfully aware that their political mobilising of workers for workplace rights and their reputation as "anti-establishment" unions made it more difficult for their workers to secure welfare benefits given the state administration's preference for tame and pliant unions that were easier to control.

From the point of view of the unions' leadership, there was no easy resolution of the dilemmas posed by the welfare boards, and battling the boards to wrest benefits for workers was deemed unavoidable. Even if the boards were indifferent to workers' needs and aspirations, leading organisers of the KTPS and CITU asserted that the unions could not afford to become indifferent to the boards. CITU state leaders observed that handling the welfare boards was like wielding a knife that could cut them if they were not careful. They acknowledged that it was a big challenge to direct workers' anger at the welfare boards away from the union and towards the government, and that doing this required sustained work in developing the "class consciousness" of informal workers and their "spirit of struggle". It also required that unions intensify their engagement in informal workers' livelihood struggles and daily lives in order to retain their trust despite the disappointing performance of the welfare boards. 


\section{Discussion}

The article has discussed at length the principal contradictions and conflicts facing trade unions in Tamil Nadu in their efforts to realise the welfare rights of informal workers promised by progressive legislation and welfare schemes. Scholars note that the labour transformation associated with informalisation, reflected in a growing multiplication and heterogeneity of work, generates pressures that fragment collectives and render more difficult union organisers' promotion of collective action among extremely poor workers whose daily struggle is to survive (Noiseux, 2016). This study has shown how trade unions of informal workers have to also contend with the divisive operational logics of welfare benefits which, by virtue of targeting diverse household consumption needs, disrupt fragile solidarities among workers when some claims are sanctioned and others refused. If the inherent logic of individual worker-targeted welfare benefits creates tensions in collective and union spaces, the encoding of welfare schemes and benefits within governmental procedure and practice further compounds the challenges before workers and their unions.

As the article has demonstrated, the processes of gaining membership and benefits from the boards entrap workers within a web of bureaucratic power that frustrates them and exhausts their resources. The welfare boards' regulations diminish trade unions' representational role by insisting that workers directly present themselves at the boards and labour offices, thereby delegitimising the unions. A new climate of opportunity created by the welfare boards was seized by entrepreneurial individuals (such as the founders of the "letter pad unions" and the hundreds of similar organisations that have sprung up in the districts), who insinuated themselves into state welfare delivery mechanisms at local level. Through the eager willingness of the state bureaucracy to cooperate with these intermediaries, the state has set the template for the modes of non-state intervention that are best suited to channel welfare benefits to informal workers. The appearance of these NGOs and their enmeshment within networks of state patronage is a phenomenon that has become increasingly common across development schemes in India. Since the inception of India's economic liberalisation from the early 1990s, the Indian state has proactively pursued collaborative partnerships with NGOs, regarded as implementers of government programmes to "tight specifications", in order to deliver development and welfare services in a cost-effective manner to low-income populations (Kudva, 2005: 246). In Tamil Nadu, well before the advent of the district labour offices in 2009 , local state actors were eager to identify grassroots NGOs to deliver microcredit and other welfare schemes, so long as they were compliant partners who limited their activities to service delivery and did not mobilise communities to confront locally embedded structures of power (Kalpana, 2015).

The political quiescence that the state seeks to cultivate through its welfare agenda raises troubling issues, some of which have been flagged in other country contexts. In China, the state has invited civic organisations to assist in implementing social policies that aim to contain worker unrest that has been growing since the onset of market reforms (Howell, 2015). Labour NGOs, whose emergence is the result of the (perceived) failure of existing trade unions to defend workers' rights, have been lured towards a statist agenda of welfare-focused cooperation that emphasises services to the exclusion of rights. Howell (2015) observes that the actors in the new civic sector of welfare provision are unlikely to be agents of social change empowering workers to organise collectively, challenging government employment policies or consciously building a labour movement. The "welfarist incorporation" of labour NGOs within the political system, she cautions, may deal a "death-kiss" to independent labour organising.

It may be argued, therefore, that there are powerful tendencies towards depoliticising or 
demobilising labour movements in the emerging field of state-sponsored provisioning of workers' welfare needs. While the global literature (reviewed in the introduction to this article) establishes that it is indeed possible for national governments, committed to an overall programme of neoliberal reforms, to take forward pro-worker legislation and policy initiatives, the Tamil Nadu case study shows that these progressive initiatives may pave the way for patronage politics seeking to blunt the radical edge of working-class mobilisations and modes of welfare activism that appear antithetical to the collectivist ethos of trade union action. Even as these pro-worker measures (in India and elsewhere) have been won through bottom-up pressures and organising by the workers themselves, this study alerts us to the possibility that the victories of the working class and its representatives may be turned into tools to discipline and tame them. And therefore, what our case study does is to show up the limits of these victories secured under conditions that are primarily adversarial to labour. In doing this, it draws attention to the underlying structural relationship between state action (or what nation-states are willing and able to do in terms of protecting labour's interests) and the wider economy where capital has decisively secured the upper hand. For instance, in the case of India, even as the state extends individual worker-oriented welfare benefits to informal workers, it shows little or no regard for the collective demands and aspirations of organised (formal and informal) workers. Workers' movements across the country have taken to the streets to protest the central government's many initiatives since 2014, such as the weakening and dilution of labour protection and enforcement laws, officially portrayed as "rigid" and "affecting employment" (Shyam Sundar, 2018; Nileena, 2019).

In the foreseeable future, it appears that both the "state logic" of maintaining political regimes in power and a "market logic" of appeasing workers and stabilising capitalist production relations (Howell, 2015) will require welfare and anti-poverty measures targeted at the working poor to continue and even expand. For labour organisers and movements (such as those of this study) who strive to politically conscientise workers and build up a grassroots resistance to macro policies that do not favour labour, the question is how to successfully navigate the treacherous minefield of patronage-infused welfare politics (or risk losing the trust and goodwill of workers) and simultaneously counter the circumscribed parameters of the "service unionism" promoted by the state as the dominant model of claiming informal workers' social protection rights. How may trade unions and labour movement organisers committed to expanding the political and economic rights of workers envision a transformative politics of asserting and defending the welfare rights of informal workers? While this article offers no definitive answer to this question, what it does is to

foreground this as a central issue that must animate debates and discussion in the field of labour studies and introspection among organisers in the years to come.

\section{REFERENCES}

Agarwala, R. (2013) Informal Labor, Formal Politics, and Dignified Discontent in India. New York: Cambridge University Press.

Baltar, P. de A., A.L. dos Santos, J.D. Krein, E. Leone, M.W. Proni, A. Moretto, A.G. Maia and C. Salas (2010) Moving towards Decent Work. Labour in the Lula Government: Reflections on Recent Brazilian Experience. Global Labour University Working Paper No. 9. Geneva: International Labour Organization. www.global-labour-university.org/fileadmin/GLU Working Papers/GLU WP No.9.pdf (accessed 9 June 2009).

Bennett, M. (2003) Organizing in the Informal Economy: A Case Study of the Clothing Industry in South Africa. SEED Working Paper No 37. Geneva: International Labour Organization. www.ilo.org/wcmsp5/groups/public/-ed emp/-emp ent/-ifp seed/documents/publication/wcms 117699.pdf (accessed 7 June 2009). 
Bhowmik, S.K. (2009) India: Labour Sociology Searching for a Direction. Work and Occupation, 36(2): 126144.

Breman, J. (2001) An Informalised Labour System: End of Labour Market Dualism. Economic and Political Weekly, 36(52): 4804-4821.

Chatterjee, P. (2008) Democracy and Economic Transformation in India. Economic and Political Weekly, 43(16): 53-62.

Cook, M.L. (2007) The Politics of Labour Reform in Latin America: Between Flexibility and Rights. University Park, PA: The Pennsylvania State University Press.

Cook, M.L. and J.C. Bazler (2013) Bringing Unions Back In: Labour and Left Governments in Latin America. Cornell University ILR School, Working Papers. https://digitalcommons.ilr.cornell.edu/workingpapers/166/ (accessed 12 June 2019).

Geetha, R. (1996) A Struggle within a Struggle: The Unionisation of Women in the Informal Sector in Tamil Nadu. In Speaking Out: Women's Economic Empowerment in South Asia, edited by Marilyn Carr, Martha Chen and Renana Jhabvala. London: IT Publications.

Ghosh, J. (2002) Globalisation, Export-oriented Employment for Women and Social Policy: A Case Study of India. Social Scientist, 30(11/12): 17-60.

Government of Tamil Nadu (GOTN) (Undated) Employment List. Tamil Nadu Manual Workers Welfare Board. www.labour.tn.gov.in/Labour/tnmanwork.jsp\# (accessed 4 September 2018).

Government of Tamil Nadu (GOTN) (2018) Policy Note 2018-2019. Labour and Employment Department. http://cms.tn.gov.in/sites/default/files/documents/labemp e pn 2018 19.pdf (accessed 8 September 2018).

Harriss, J. (2011) How Far have India's Economic Reforms been "Guided by Compassion and Justice”? Social Policy in the Neoliberal Era. In Understanding India's New Political Economy: A Great Transformation? edited by Sanjay Ruparelia, Sanjay Reddy, John Harriss and Stuart Corbridge. London and New York: Routledge.

Howell, J. (2015) Shall We Dance? Welfarist Incorporation and the Politics of State-Labour-NGO Relations in China. The China Quarterly, 223: 702-723.

Kalpana, K. (2015) SHG Intermediation and Women's Agency: A View from Tamil Nadu. In Microfinance in India: Approaches, Outcomes, Challenges, edited by Tara Nair. London, New York and New Delhi: Routledge.

Khera, R. (2017) Impact of Aadhaar on Welfare Programmes. Economic and Political Weekly, 52(50): 61-70.

Kudva, N. (2005) Strong States, Strong NGOs. In Social Movements in India: Poverty, Powver and Politics, edited by Raka Ray and Mary Fainsod Katzenstein. Lanham, MD: Rowman \& Littlefield.

Nileena M.S. (2019) Trade Unions Protest against Modi’s "Pro-corporate" and "Anti-people" Labour Reforms. The Caravan. https://caravanmagazine.in/policy/trade-unions-against-modi-labour-policies (accessed 16 June 2019).

Noiseux Y. (2016) Organizing in the Informal Sector: A Case Study in Mumbai's Shipbreaking Yards. International Critical Thought, 6(2): 245-266.

PRS Legislative Research (PRS) (Undated) The Tamil Nadu Manual Worker (Regulation of Employment and Conditions of Work) Act, 1982, plus Amendments. Laws of India: A Project of PRS Legislative Research. www.lawsofindia.org/pdf/tamil nadu/1982/1982TN33.pdf (accessed 2 September 2018).

Shyam Sundar K.R. (2018) India's Mismanagement of Labour Law Reform Continues with the Modi Government. The Wire. https://thewire.in/labour/labour-law-reform-narendra-modi-government (accessed 16 June 2019).

Srivastava, R. (2012) Changing Employment Conditions of the Indian Workforce and Implications for Decent Work. Global Labour Journal, 3(1): 63-90. 
Standing, G. (1999) Global Feminization through Flexible Labor: A Theme Revisited. World Development, 27(3): 583-602.

Subramanian N. (1999) Ethnicity and Populist Mobilization: Political Parties, Citizens and Democracy in South India. New Delhi: Oxford University Press.

Tamil Nadu Manual Workers Welfare Board and 13 Other Boards (TNMWWB) (Undated) Information Handbook. Under "Right to Information Act 2005". http://www.tn.gov.in/rti/proactive/labour/handbook welfareboards.pdf (accessed 5 September 2018).

Tilly, C., R. Agarwala, S. Mosoetsa, P. Ngai, C. Salas and H. Sheikh (2013) Informal Worker Organizing as a Strategy for Improving Subcontracted Work in the Textile and Apparel Industries in Brazil, South Africa, India and China. University of California, Los Angeles: Institute for Research on Labour and Employment.

Torres, L. (2005) Labour and Politics in South Africa. In Democratising Development: The Politics of Socio-Economic Rights in South Africa, edited by Peris Jones and Kristian Stokke. Leiden, The Netherlands: Koninklijke Brill.

\section{Interviews}

R. Geetha, founding member of KTPS and State Coordinator of Unorganised Workers Federation, interviewed 25 January 2018.

Malathi Chittibabu, State Treasurer of the CITU, interviewed 1 August 2018.

R. Singaravelu, State Vice-President of the CITU, interviewed 6 July 2018.

Vasanthi, Joint Secretary of the CITU Informal Sector Workers Union (Chennai District), interviewed 19 March 2018.

Sasikala, District Secretary of KTPS (Madurai District), interviewed 28 February 2018.

\section{BIOGRAPAHICAL NOTE}

K. Kalpana is Assistant Professor in the Department of Humanities and Social Sciences, IIT Madras, Chennai. Her research interests include gender, poverty, labour and microcredit. She is the author of Women, Microfinance and the State in Neo-liberal India (Routledge, 2017). [Email: kkalpana@,iitm.ac.in] 